\title{
Review
}

\section{Nuclear transplantation: reprogramming of transplanted nuclei}

\author{
Jiří Kaňka \\ Institute of Animal Physiology and Genetics, Academy of Sciences of the Czech Republic, \\ 27721 Libechov, Czech Republic
}

(Received 21 June 1999; accepted 12 July 1999)

\begin{abstract}
Recent results in animal cloning have demonstrated that the events of cell differentiation can be reversed. This reversal necessarily requires genetic reprogramming of the transplanted nucleus. It has emerged from review articles that synthesis of nuclear and ribosomal RNA is blocked after fusion independently of cell cycle stage of the transferred nucleus, and that the cytoplasm condition of the cytoplast controls the speed of this inhibition. Transcription of the embryonic genome in nuclear transplant embryos begins either at the same stage as in normal development or even earlier. Expression analysis of individual genes showed up differences between nuclear transplant and normal embryos at the blastocyst stage. A certain degree of nuclear reprogramming after fusion is necessary, but exact timing and the qualitative sequence of the processes are probably not necessary for the successful embryonic development of the cloned embryo. In the future, observation of the expression of individual genes will bring more exact information about nucleus reprogramming. (C) Inra/Elsevier, Paris
\end{abstract}

embryo / cloning / reprogramming / nucleic acid

Résumé - Transfert nucléaire : la reprogrammation des noyaux transplantés. Les résultats récents du clonage animal ont démontré que la différenciation cellulaire est réversible. Cette réversibilité nécessite une reprogrammation génétique du noyau transplanté. Il ressort des articles révisés que la synthèse d'ARN nucléaires et ribosomiaux est bloquée après la fusion, indépendamment du stade du cycle cellulaire du noyau transféré et que l'état du cytoplasme contrôle la vitesse de cette inhibition. La transcription du gènome embryonnaire après transfert nucléaire débute au même stade qu'au cours du développement embryonnaire normal, voire même plus tôt. L'analyse de l'expression de certains gènes indique des différences entre les embryons issus de transferts nucléaires et les embryons normaux au stade blastocyste. Un certain niveau de reprogrammation nucléaire après fusion est nécessaire mais, une synchronisation et une chronologie exactes des processus ne sont peut-être pas indispensables au développement des embryons clonés. Dans le futur, l'analyse de l'expression de gènes particuliers apportera plus d'information exactes sur la reprogrammation nucléaire. (C) Inra/Elsevier, Paris

embryon / clonage / reprogrammation / acide nucléique

E-mail:kanka@site.cas.cz 


\section{INTRODUCTION}

The evolution of nuclear transplantation in mammals has recently leapt ahead. While the first cloned mammal from a somatic cell - the sheep Dolly - was welcomed with distrust and misgivings, today this type of experiment is a reality that nobody can doubt. There are many scientific teams able to implement this experimental procedure and there is also an increased number of animal species that have been successfully cloned from somatic and differentiated cells (sheep, mice, cattle, goats). We still only know a little bit about what happens to the nucleus of the somatic cell after it is transferred to the cytoplasm of an oocyte, how the nucleus is reprogrammed and how much of this reprogramming is really necessary for the successful development of a newly created cloned individual [9].

\section{METHODS OF NUCLEAR TRANSPLANTATION}

The nuclear transplantation of farm animals is performed by fusion of a donor cell (or karyoplast) to an oocyte or zygote from which the genetic material has been removed (cytoplast, recipient). In farm animal species, the recipient cell is usually the secondary oocyte. The first method of enucleation is the separation of an oocyte into two halves, so that one of the halves does not contain the nucleus [44]. This method is simple, but it essentially reduces the contents of the cytoplasm. The second method, which is based on the direct removal of the second metaphase (MII) chromosomes, results in the removal of a smaller proportion of the cytoplasm [4]. This is more convenient for the further successful development of the embryo. Following enucleation, the genetic material from the donor cell must be introduced into the enucleated recipient cell. In farm animals, the most commonly used method is the application of an electric pulse
[44]. At the place of contact between donor and recipient cells, membranes are dissolved and the nucleus of the donor cell will appear in the area of the cytoplasm of the enucleated oocyte. If the experiment is run successfully, a newly reconstructed embryo will begin embryogenesis.

\section{INTERACTION OT THE CELL CYCLE STAGES OF DONOR AND RECIPIENT CELLS}

Upon transfer of the nuclei, the donor cell moves into the area of the enucleated oocyte. But each of these two components can be found in a different stage of the cell cycle.

The eukaryotic cell (donor cell) can be situated in one of four different stages of the cell cycle indicated as $G_{1} S, G_{2}$ and $M$. The discrete period of DNA synthesis or $S$ phase is preceded by the $G_{1}$ or pre-DNA synthetic period and followed by the $G_{2}$ or post-DNA synthetic period. The $G_{2}$ phase is followed by the $S$ phase, or mitosis, when segregation of the duplicated genetic material occurs. This is followed by cell division [27].

A cytoplast (recipient) in the MII phase or $S$ phase of the cell cycle (after activation of the oocyte) is usually used. The MII cytoplasm of oocytes, which is most often used as a source of cytoplasts for farm animals, has a high MPF level (mitosis/meiosis/maturation promoting factor). This factor is responsible for the onset of both mitosis and meiosis [26]. After insemination or activation of the oocyte, the MPF level decreases and remains low during the $S$ phase. A high MPF level is responsible for nuclear envelope breakdown (NEBD) and the condensation of chromatin either throughout a normal mitotic (or meiotic) cycle, or in the transferred nucleus [8]. A high MPF level will cause NEBD and condensation of chromatin at the transferred nucleus regardless of the cell stage into which the nucleus has just 
been transplanted. These processes are followed by DNA replication again, regardless of the actual level of DNA content in the transferred nucleus. The result of this is that during transfer into the MII cytoplasm of the oocyte, it is only possible to use the donor nucleus in $\mathrm{G}_{1}$. If the donor nucleus is in the $S$ or $G_{2}$ phase of the cell cycle, chromatin damage occurs, probably with an excessive synthesis of DNA. On the contrary, after transfer into an $S$ phase cytoplast (after activation) when MPF activity has declined, the stage of the cell cycle of the nucleus determines whether or not DNA replication has occurred. DNA replication has been observed in $G_{1}$ and $S$ phase nuclei, but not in the $\mathrm{G}_{2}$ nuclei phase [4]. An activated oocyte in which MPF activity has decayed provides a suitable cytoplast for cells at any stage of the cell cycle. Clarification of these theoretical principles is the significant scientific success of Campbell et al. [5]. It should be noted that similar results have also been obtained by Barnes et al. [2] for cloned embryos of cattle.

It is necessary to emphasise that it is difficult to compare the results obtained by different groups because of different cytoplast preparation methodologies. Campbell et al. [4] suggest that many previous studies and also commercial procedures have unintentionally used preactivated oocytes. Routinely used recipient oocytes are usually far older than those used for in vitro fertilisation. Aged oocytes are activated by minor changes in the environment, such as changes in temperature or exposure to a fusion medium. As a result, at the time of fusion the oocyte is no longer equivalent to one at MII, but rather is similar to a cytoplast in the $S$ phase.

In 1997, a fundamental study by scientists from the Roslin Institute was published that has changed our opinions on the possibility of mammal cloning. While in the past cloned animals were obtained from embryonic undifferentiated cells, the cloned sheep Dolly was obtained from cells of the mam- mary gland of an adult sheep. Cells of the mammary gland were cultivated in a medium with a low content of foetal calf serum (FCS), which resulted in the termination of the cell cycle at the stage named $\mathrm{G}_{0}$ (quiescent compartment of $\mathrm{G}_{1}$ ). The authors supposed that this stage helps to better reprogram the transferred nucleus. A part of the scientific public first reacted sceptically to the birth of the sheep Dolly; they pointed out the insufficient definition of applied cells and the very low success rate. But the experiment of the Yanagimashi group [40] followed, which proved that cloning is also possible for another type of animal (mouse) and from another, well-defined source of cells (cumulus cells naturally arrested in $G_{0}$ ). The group of $Y$. Tsunoda [38], using trophoblast cells in the $G_{1}$ phase repeated the mice cloning. Wells et al. [42] obtained ten cloned calves after fusion of mural granulosa cells (after cultivation in a medium with a low FCS content in $\mathrm{G}_{0}$ ) with enucleated metaphase II cytoplasts. The fusions were made $4-6 \mathrm{~h}$ before the activation of the cytoplasts, so that the transferred nuclei were in the cytoplasmic area with a high MPF level for a longer time.

Interestingly, all four scientific groups used different cloning methods. It seems then that many protocols exist that cause the nuclei of the somatic cell to return to the undifferentiated stage.

\section{NUCLEAR REMODELLING}

Although successful cloning from somatic cells of adult individual sheep [45], mice $[38,40]$, cattle $[18,42]$ and from foetal somatic cells of a goat [1] has been carried out, we do not know exactly what processes occur in the nucleus of the differentiated cell after transfer into the cytoplasm of the oocyte or the extent of nuclear reprogramming that is necessary for further embryogenesis. 


\section{TEMPORAL DEVELOPMENTAL PATTERN}

The first morphological evaluation of nuclear remodelling in mammals came from experiments in the rabbit [35]. In these studies, the time required to progress from the zygote to the blastocyst stage was similar (approximately $120 \mathrm{~h}$ ) for fertilised embryos and nuclear transfer embryos (eight-cell stage donor nuclei). An eight-cell stage blastomere, however, not transferred into an unfertilised embryo (not remodelled) formed a blastocoele cavity within $72 \mathrm{~h}$. Therefore, the donor nuclei were reprogrammed, since they reverted to the same morphological and temporal developmental pattern as the zygote [36].

\section{PROTEIN SYNTHESIS LEVEL}

A nuclear transfer experiment in the pig has shown that a 16 -cell stage blastomere which is lamin $\mathrm{A} / \mathrm{C}$ negative becomes lamin A/C positive after transfer to an enucleated MII oocyte [31]. Furthermore, in the pig it was found that the Y12 epitope (a protein epitope of the small nuclear ribonuclear protein), which is present on the blastomeres at the 16-cell stage, is no longer detected after nuclear transfer and culture [30]. It was not shown, however, in either study whether the expression of the lamin $\mathrm{A} / \mathrm{C}$ or Y 12 epitope would follow the normal pattern if the nuclear transfer pig embryo would develop to the 16-cell stage and beyond.

A more perfect study was performed with the developmentally regulated antigen TEC-3 that is expressed during bovine preimplantation development on morulae and blastocysts. TEC- 3 is absent from unfertilised and fertilised oocytes, and from all stages before the 32-cell stage. Nuclear transfer embryos were made by electrical fusion of blastomeres from morulae with enucleated MII oocytes. The TEC-3 antigen, present on blastomeres of the morula stage embryo, disappeared after fusion and was expressed again when the nuclear transfer embryos developed to the morula and blastocyst stage [39].

\section{NUCLEAR RNA (RIBONUCLEIC ACID) SYNTHESIS LEVEL}

One indication of nucleus reprogramming is the nuclear RNA synthetic activity. In normal bovine embryogenesis, the embryo relies upon maternally derived RNA transcripts up to the eight-cell stage, at which time it begins to transcribe its own RNA [3, $19,20]$. In the experiment by Smith et al. [34], RNA synthesis was detected in nuclear transfer embryos and control embryos by pulsing with ${ }^{3} \mathrm{H}$-uridine, fixation and autoradiography on semithin sections. Nuclear transfer embryos were produced using either a MII phase (non-activated) cytoplast or $S$ phase (activated) cytoplast activated with the calcium ionophore A23187 and cycloheximide treatment for $8 \mathrm{~h}$ prior to fusion with a blastomere from an in-vitro-produced morula stage embryo. In-vitro-produced embryo controls were ${ }^{3} \mathrm{H}$-uridine labelled and fixed at the two-, four-, early eight- and late eight-cell stages. Nuclear transfer embryos were similarly prepared at 1,3 and $20 \mathrm{~h}$ postfusion and at the two-, four- and eight-cell stages. In the control embryos, RNA synthesis was absent in the two-, fourand early eight-cell stages, whereas in all late eight-cell stages, it was present. In nucleus transfer embryos from non-activated (MII phase) cytoplasts, there was a sharp decline in RNA synthesis 1 and $3 \mathrm{~h}$ after fusion and a total absence $20 \mathrm{~h}$ after fusion. On the contrary, nucleus transfer embryos from activated ( $S$ phase) cytoplasts exhibited continuous high levels of RNA synthesis $1 \mathrm{~h}$ and moderate levels $3 \mathrm{~h}$ after fusion, although they ceased $20 \mathrm{~h}$ after fusion. There was no RNA synthesis seen at the two-cell stage in all nucleus transfer embryos (activated and non-activated cytoplasts). At the four-cell stage, however, weak RNA synthesis was seen in all nuclear trans- 
fer embryos from activated cytoplasts, whereas none was observed in those from MII non-activated cytoplasts. At the eightcell stage, nearly all nuclear transfer embryos from $S$ phase cytoplasts showed weak to moderate levels of RNA synthesis. The authors concluded that nuclear reprogramming differs for nuclear transfer embryos reconstructed from activated and non-activated cytoplasts with the former undergoing a slower cessation of RNA synthesis after fusion and earlier resumption of RNA synthesis, occurring as early as the four-cell stage.

Kaňka et al. [14] performed a similar experiment on cattle embryos; the difference was that the enucleation of the oocyte in the MII stage was made by bisection. The enucleated half of the oocyte was fused with a cell in the late eight-cell stage, which actively synthesised a nuclear RNA. This RNA synthesis was arrested during three cell cycles following fusion. The activation appeared during the eight-cell stage of the reconstructed embryo, after the same number of cell cycles after fusion as in nonmanipulated bovine embryos after fertilisation.

Lavoir et al. [23] investigated the reprogramming of blastomere nuclei from 16- to 32-cell stage in-vitro-fertilised bovine embryos following nuclear transfer by fusion of individual blastomeres with cytoplasts prepared from oocytes at two different stages of maturation. Heterogeneous RNA production and protein profiles of nuclear transfer embryos (up to the eight-cell stage) were analysed. In all nuclear transfer embryos analysed for their RNA production, ${ }^{3} \mathrm{H}$-uridine incorporation was higher at the one-, two- and four-cell stages than in the in vitro fertilised bovine embryo controls.

Hyttel et al. [11, 12] investigated the RNA synthesis in porcine blastomere nuclei after transplantation into enucleated MII oocytes. Nuclei from two- to eight-cell porcine embryos were introduced into the cytoplasm of enucleated porcine oocytes by electrofusion and the resultant reconstructed embryos were cultured in vitro. Embryos were incubated with ${ }^{3} \mathrm{H}$-uridine at different intervals, fixed and histologically processed for autoradiography. All blastomeres displayed pronounced RNA synthesis before fusion. At 3 and $9 \mathrm{~h}$ after fusion, the synthesis decreased or ceased. Some embryos resumed RNA synthesis at the one- to twocell stage, earlier than the four-cell stage when synthesis begins in normal pig embryogenesis [37]. Ouhibi et al. [28] also found that RNA synthesis in the reconstructed embryo would be stopped after fusion of the pig ectodermal cell with the oocyte enucleated in MII.

A similar study was also made on the rabbit embryo [16], where changes in the level of transcriptional activity in 32-cell stage morula nuclei were studied after transplantation to enucleated oocytes by electrofusion. The authors assumed that the oocyte used was MII, but they did not know the MPF level. It is therefore possible that they actually transferred cells closely resembling the S phase into the cytoplast (see section 3 or Campbell et al. [4]). Nuclear transplant recipients were labelled with ${ }^{3} \mathrm{H}$-uridine during cultivation in vitro, the embryos were then fixed and processed for autoradiography. Transcriptional activity was substantially decreased after $4.5 \mathrm{~h}$ and completely inhibited 12 or $15 \mathrm{~h}$ after fusion.

RNA synthesis was first detected in twocell stage control rabbit embryos $[13,15]$, but this synthesis was unaltered by alphaamanitin, indicating the synthesis of a nonpolymerase II-dependent RNA species. Alpha-amanitin-sensitive transcription was first detected in four-cell stage control embryos. Transcription in nuclear transfer embryos resumed after cell division at the two-cell stage and $70 \%$ of the examined embryos had both nuclei labelled. Transcription activity then rapidly increased through the 16-cell stage reaching a level typical of the 32-cell stage nuclei used for transfer. 
Thus, the cytoplasm of the oocyte enucleated in the MII or S phase is able to block transcriptional activity (which was discovered by autoradiography) of the donor nucleus. The inhibiting effect apparently did not depend on the cell cycle phase of the donor nucleus and was only attributable to the oocyte cytoplasm because the blastomere cells used for transfer were not synchronised before fusion. Differences exist in the speed of RNA synthesis inhibition and this inhibition is executed faster in the MII oocyte cytoplasm. A new RNA synthesis in nuclear transplant nuclei begins at the same developmental stage as for the normal embryo, and for some mammal species even one cellular cycle earlier.

\section{RIBOSOMAL RNA SYNTHESIS AND NUCLEOLAR ULTRASTRUCTURE}

The first work indicating the occurrence of a change in ribosomal RNA (rRNA) synthesis after nuclei transfer was executed on the mouse model. In the mouse, rRNA synthesis is not detected until the two-cell stage is achieved [6]. This is why the nucleolar organising regions (NOR) can only be visualised in mouse metaphase chromosomes from the two-cell stage and onwards. When eight-cell stage NOR positive nuclei are transferred into one-cell stage embryos, positive NOR are not detected [7]. This means that rRNA synthesis is inhibited after nucleus transfer into the cytoplasm of the one-cell stage.

Changes in the nucleolar ultrastructure during early embryonic development enable us to determine whether the nucleolus is active or not and whether it synthesises rRNA. Therefore, the nucleolus represents a unique model, where we can directly observe the activity of ribosomal genes under an electron microscope.

The ultrastructural morphology of the nucleoli during early bovine embryonic development was described by Kopečný et al. [20]. This description is valid only for horned cattle embryos and the nucleolus ultrastructure differs for individual mammal species during embryonic development.

- Stage 1: nucleolar precursor body. The nucleolar precursor body is a mass of more or less homogeneously distributed, densely packed fibrils. No ${ }^{3} \mathrm{H}$-uridine incorporation has been detected. The nucleolar precursor bodies are associated with large electrondense granules and condensed chromatin [21, 22].

- Stage 2: vacuolated nucleolar precursor body. In the centre of the nucleolar precursor body appears an electron-lucid area signifying a start of the vacuolisation process. At this stage, the nucleolar precursor body is associated with a clump of condensed chromatin. No ${ }^{3} \mathrm{H}$-uridine incorporation was detected.

- Stage 3: nucleolus with secondary vacuoles. Detected ${ }^{3} \mathrm{H}$-uridine incorporation indicates that the nucleolar precursor body has been transformed into a functional, rRNA synthesising nucleolus. The active nucleolus is formed by intermingled filamentous components and intranucleolar granules. A still large primary vacuole and new secondary vacuoles exhibit an irregular outline which is in contrast to a typical clearcut boundary of the primary vacuole of the stage 2 nucleolus.

- Stage 4: reticulated fibrillogranular nucleolus. The number of intranuclear granules increases until they represent a major component of the nucleolus. Due to granule accumulation, the originally rounded nucleolus gains an irregular shape, which can first be seen in the 16-cell stage embryo.

Kaňka et al. [17] examined nucleolar ultrastructure in bovine in-vitro-produced (control) embryos and in nuclear transfer embryos reconstructed from MII phase (nonactivated) or $\mathrm{S}$ phase (activated) cytoplasts. Control embryos possessed a nucleolar precursor body (stage 1) throughout all three cell cycles. In the eight-cell stage embryo, a 
primary vacuole appeared as an electron lucid area originating in the centre of the nucleolar precursor body (stage 2).

In nuclear transfer embryos reconstructed from MII (non-activated) cytoplasts, the nuclear envelope was fragmented or completely broken down $1 \mathrm{~h}$ after fusion and was restored again $3 \mathrm{~h}$ after fusion. At this time, the reticulated fibrillo-granular nucleolus had an almost round shape. The nucleolar precursor body seen in the two-cell stage nuclear transfer embryos consisted of intermingled filamentous components and secondary vacuoles. A nucleolar precursor body typical of the two-cell stage control embryos was never observed. None of the reconstructed embryos of this group reached the eight-cell stage.

Nuclear transfer embryos reconstructed from $S$ phase (activated) cytoplasts, on the contrary, exhibited a complete nuclear envelope at all time intervals after fusion. In the two-cell stage nuclear transfer embryos, the originally reticulated nucleolus of the donor blastomere had changed into a typical nucleolar precursor body consisting of a homogeneous fibrillar structure. A primary vacuole appeared in the four-cell stage nuclear transfer embryos, which was one cell cycle earlier than in control embryos.

The authors concluded that only nuclear transfer embryos reconstructed from activated cytoplasts undergo complete reprogramming of the nucleolus. The reorganisation of the donor nucleolar architecture into a functionally active nucleolus was observed as early as in the four-cell stage nuclear transfer embryo. These ultrastructural observations were correlated with autoradiographic data for the initiation of RNA synthesis in nuclear transfer embryos [34].

A similar study was also made on the rabbit embryo model [16]. In this experiment, oocytes were enucleated in the MII stage. Considering that the authors did not follow the MPF level in the cytoplasm, it is also possible that the nuclei were fused into the cytoplast, which was similar to the $\mathrm{S}$ phase cytoplast.

Changes in the nucleolar ultrastructure after nuclear transfer reflect the inhibition and subsequent reactivation of rRNA transcription. The nucleoli of 32-cell rabbit embryos had typical arrangements of active nucleoli: many fibrillar centres covered and interconnected by threads of dense fibrillar components, embedded into granular components. Ten to fifteen hours following nuclear transplantation, these nucleoli underwent drastic changes including a loss of granular material, collapse of nucleolar structure and segregation of nucleolar components. Following a first cleavage, segregated fibrillar components of nucleoli manifested a complete inhibition of nucleolar transcription. Ribosomal RNA transcription was restored at the eight-cell stage and the sequence of ultrastructural changes was similar to that of normal rabbit development. At the 32-cell stage, however, excessive extrusion of pre-ribosomal particles into the cytoplasm occurred, suggesting the possible alteration of ribosome delivery regulating mechanisms.

Ouhibi et al. [29] investigated the changes in nucleolar ultrastructure and the synthesis of ribosomal RNA in reconstructed pig embryos obtained by electrofusion of a single pig ectodermal cell to an enucleated metaphase-II oocyte. The nucleolar morphological changes and the pattern of transcription were examined in the ectodermal cells before fusion and in nuclear transfer reconstructed embryos $16-18 \mathrm{~h}$ after fusion. Before fusion, the ectodermal cells exhibited a reticulated nucleolus with active RNA synthesis. In the reconstructed embryos, modifications of the nucleolar structure were observed, as assessed by the presence of either round-shaped, compact, dense nucleolar precursor bodies or reticulated nucleoli. In both cases, however, there was no RNA synthesis. Blebbing activity of the nuclear envelope was not observed. These results indicate that the nucleus of pig ecto- 
dermal cells exhibits either a complete or an incomplete remodelling when transferred to an enucleated metaphase-II oocyte, with no detectable RNA synthesis.

All studies of the nucleolus ultrastructure conform to previous studies of RNA synthesis. Ultrastructural changes occur in all cases after nuclei transfer with active nucleoli, which are characteristics of nonactive nucleolus. Nucleolus activation occurs during the development of a nuclear transplant embryo again at the same stage as with normal development, and eventually one cellular cycle earlier.

\section{MOLECULAR GENETICS}

One of the most valuable and still scarce pieces of direct evidence on reprogramming is the analysis of gene expression patterns in cattle blastocysts produced in vivo and in vitro by nuclear transfer [43]. In this study, nuclear transfer blastocysts possessed both a high level of transcripts for the IGF-I receptor and growth factors IGF-II and TGFalpha as well as a low level of transcripts for growth factor IGF-I in comparison with in-vivo- and in-vitro-produced blastocysts. Transcripts for the growth factor bFGF were detected in nuclear transfer blastocysts but not in in-vivo and in-vitro blastocysts. Clearly, the patterns of gene expression in nuclear transfer embryos are different from those of normal embryos.

\section{CONCLUDING REMARKS AND FUTURE PROSPECTS}

Considering that individual groups use different protocols for nuclear transfer, it is very difficult to compare the results. It follows from previous articles that the synthesis of nuclear and ribosomal RNA is blocked after fusion whatever the cellular cycle stage of the transferred nucleus; the cytoplasm condition of cytoplast control regulates this inhibition. Transcription of the embryonic genome in nuclear transplant embryos begins either sooner than with normal development [34], or in the same state as with normal development, but it runs through more intensively [16]. Expression analysis of individual genes showed differences in the blastocyst stage for nuclear transplant and normal embryos [43]. A certain level of nuclear reprogramming after fusion is necessary; however, exact timing and the qualitative sequence of processes are probably not necessary for the successful embryonic development of the cloned embryo.

In the future, more precise information about nuclear reprogramming will be obtained by observing the expression of individual genes. The number of known genes, which play a part in early embryonic development, will grow by the use of successfully developed techniques for $\mathrm{mRNA}$ differential display $[10,24,25,32,46]$. Nuclear genetic methodologies will also answer the question whether the failure of imprinted genes $[33,41]$ is often responsible for the embryonic deaths of cloned individuals.

\section{ACKNOWLEDGEMENTS}

The author apologises to all those whose work could not be quoted due to the lack of space. This work was partly supported by a grant from the Agency of Academy of Science of the Czech Republic A7045904/1999.

\section{REFERENCES}

[1] Baguisi A., Behboodi E., Melican D.T., Pollock J.S., Destrempes M.M., Cammuso Ch., Williams J.L., Nims S.D., Porter C.A., Midura P., Palacios M.J., Ayres S.L., Denniston R.S., Hayes M.L., Ziomek C.A., Meade H.M., Godke R.A., Gavin W.G., Overstrom E.W., Echelard Y., Production of goats by somatic cell nuclear transfer, Nat. Biotechnol. 17 (1999) 456-461.

[2] Barnes F.L., Collas P., Powell R., King W.A., Westhusin M., Shepherd D., Influence of recipient oocyte cell cycle stage on DNA synthesis, nuclear envelope breakdown, chromosome constitution, and development in nuclear transplant bovine embryos, Mol. Reprod. Dev. 36 (1993) 33-41. 
[3] Camous S., Kopečný V., Fléchon J.-E., Autoradiographic detection of the earliest stage of ${ }^{3} \mathrm{H}$-uridine incorporation into the cow embryo, Biol. Cell 58 (1986) 195-200.

[4] Campbell K.H.S., Ritchie W.A., Wilmut I., Nuclear-cytoplasmic interactions during the first cell cycle of nuclear transfer reconstructed bovine embryos: Implications for deoxyribonucleic acid replication and development, Biol. Reprod. 49 (1993) 933-942.

[5] Campbell K.H.S., Ritchie W.A., McWhir J., Wilmut I., Featured article: cloning farm animals by nuclear transfer: from cell cycles to cells, Embryo Transfer Newslett. 14 (1996). 12-17.

[6] Clegg K.B., Piko L., Quantitative aspects of RNA synthesis and polyadenylation in 1-cell and 2-cell mouse embryos, J. Embryol. Exp. Morph. 74 (1983) 169-182.

[7] Dyban A.P., Lee K., O'Neill G.T., Speirs S., Kaufman M.H., Cytogenetic study of silverstaining NOR in 8-cell-stage mouse blastomeres fused to 1-cell-stage embryos, Development 104 (1988) 453-463.

[8] Fulka J., First N. L., Moor R.M., Nuclear transplantation in mammals: Remodelling of transplanted nuclei under the influence of maturation promoting factor, Bioessays 18 (10) (1996) 835-840.

[9] Fulka J., First N.L., Loi P., Moor R.M., Cloning by somatic cell nuclear transfer, Bioessays 20 (1998) 847-851.

[10] Henrion G., Brunet A., Renard J.P., Duranthon V., Identification of maternal transcripts that progressively disappear during the cleavage period of rabbit embryos, Mol. Reprod. Dev. 47 (4) (1997) 353-362.

[11] Hyttel P., Procházka R., Smith S., Kaňka J., Greve T., Hoier R., Transcriptional activity of porcine blastomere nuclei introduced into in vitro matured ooplasm, Theriogenology 33 (1990) 252 (Abstr.).

[12] Hyttel P., Procházka R., Smith S., Kaňka J., Greve T., RNA synthesis in porcine blastomere nuclei introduced into in vitro matured ooplasm, Acta Vet. Scand. 34 (1993) 159-167.

[13] Kaňka J., Fléchon J.-E., Début de la synthèse d'ARN et contenu en ARNm poly A dans l'embryon de lapin au cours de la segmentation, Coll. Soc. Fr. Etudes Fertil. 26 (1988) 347 (Abstr.).

[14] Kaňka J., Fulka J. Jr, Fulka J., Petr J., Nuclear transplantation in bovine embryo: Fine structural and autoradiographic studies, Mol. Reprod. Dev. 29 (1991) 110-116.

[15] Kaňka J., Fléchon J.-E., Šutovský P., Onset of RNA synthesis and poly (A) content of early rabbit embryos. Comparison with sheep, Reprod. Nutr. Dev. 33 (1993) 465-474.
[16] Kaňka J., Hozák P., Heyman Y., Chesne P., Degrolard J., Renard J.P., Fléchon J.E., Transcriptional activity and nucleolar ultrastructure of embryonic rabbit nuclei after transplantation to enucleated oocytes, Mol. Reprod. Dev. 43 (2) (1996) 135-144.

[17] Kaňka J., Smith S.D., Soloy E., Holm P., Callesen H., Nucleolar ultrastructure in bovine nuclear transfer embryos, Mol. Reprod. Dev. 52 (3) (1999) 253-263.

[18] Kato Y., Tani T., Sotomaru Y., Kurokawa K., Kato J., Doguchi H., Yasue H., Tsunoda Y., Eight calves cloned from somatic cells of a single adult, Science 282 (1998) 2095-2098.

[19] Kopečný V., Specific features of bovine embryonic nucleogenesis: a review of fine - structure autoradiographic and immunoelectron microscope studies, The Annual of the Scandinavian Society for Electron Microscopy, SCANDEM 92, Lyngby, Denmark, 1992.

[20] Kopečný V., Fléchon J.E., Camous S., Fulka J. $\mathrm{Jr}$, Nucleologenesis and the onset of transcription in the eight-cell bovine embryo: fine-structural autoradiographic study, Mol. Reprod. Dev. 31 (1) (1989) 79-90.

[21] Lauriňcík J., Hyttel P., Baran V., Lucas-Hahn A., Eckert J., Pivko J., Schmoll F., Schellander K., Pronucleus development and organization of intranuclear bodies during the first bovine embryonic cell cycle in vitro, Theriogenology (1997) 326.

[22] Lauriňčík J., Hyttel P., Baran V., Eckert J., Lucashahn A., Pivko J., Niemann H., Brem G., Schellander K., A detailed analysis of pronucleus development in bovine zygotes in vitro: Cell-cycle chronology and ultrastructure, Mol. Reprod. Dev. 50 (2) (1998) 192-199.

[23] Lavoir M.C., Kelk D., Rumph N., Barnes F., Betteridge K.J., King W.A., Transcription and translation in bovine nuclear transfer embryos, Biol. Reprod. 57 (1) (1997) 204-213.

[24] Liang P., Pardee A.B., Differential display of eukaryotic messenger RNA by means of the polymerase chain reaction, Science 257 (1992) 967-971.

[25] Liang P., Zhu W., Zhang X., Guo Z., Connell R.P.O., Averboukh L., Wang F., Pardee A.B., Differential display using one-base anchored oligo-dT primers, Nucleic Acids Res. 22 (1994) 5763-5764.

[26] Nurse P., Universal control mechanism regulating the onset of M-phase, Nature 344 (1990) 505-507.

[27] Ofarrell P.H., Edgar B.A., Lakich D., Lehner C.F., Directing cell division during development, Science 246 (4930) (1989) 635-640.

[28] Ouhibi N., Fulka J., Kaňka J., Moor R.M., Nuclear transplantation of ectodermal cells in pig oocytes: Ultrastructure and radiography, Mol. Reprod. Dev. 44 (4) (1996) 533-539. 
[29] Ouhibi N., Kaňka J., Horska M., Moor R.M., Fulka J. Jr, Nuclear transplantation in pigs: M-phase karyoplast to M-phase cytoplast fusion, Reprod. Nutr. Dev. 36 (1996) 1-6.

[30] Prather R.S., Rickords L.F., Developmental regulation of an snRNP core protein epitope during pig embryogenesis and after nuclear transfer for cloning, Mol. Reprod. Dev. 33 (1992) 119-123.

[31] Prather R.S., Sims M.M., First N.L., Nuclear transplantation in early pig embryos, Biol. Reprod. 41 (1989) 414-418.

[32] Schultz R.M., Worrad D.M., Davis D.M., Desousa P.A., Regulation of gene expression in the preimplantation mouse embryo, Theriogenology 44 (8) (1995) 1115-1131.

[33] Seamark R.F., Progress and emerging problems in livestock transgenesis: A summary perspective, Reprod. Fertil. Dev. 6 (5) (1994) 653-657.

[34] Smith S.D., Soloy E., Kaňka J., Holm P., Callesen $\mathrm{H}$., Influence of recipient cytoplasm cell stage on transcription in bovine nucleus transfer embryos, Mol. Reprod. Dev. 45 (4) (1996) 444-450.

[35] Stice S.L., Robl J.M., Nuclear reprogramming in nuclear transplant rabbit embryos, Biol. Reprod. 39 (1988) 657-664.

[36] Stice S.L., Robl J.M., Ponce de Leon F.A., Jerry J., Golueke P.G., Cibelli J.B., Kane J.J., Cloning: new breakthroughs leading to commercial opportunities, Theriogenology 49 (1998) 129-138.

[37] Tománek M., Kopečný V., Kaňka J., Genome reactivation in developing early pig embryos: an ultractructural and autoradiographic analysis, Anat. Embryol. 180 (1989) 309-316.

[38] Tsunoda Y., Kato Y., Not only inner cell mass cell nuclei but also trophectoderm nuclei of mouse blastocysts have a developmental totipotency, J. Reprod. Fertil. 113 (2) (1998) 181-184.
[39] van Stekelenburg-Hamers A.E.P., Rebel H.G., van Inzen W.G., d. L.F., Drost M.A., Mummery C.L., Weima S.M., Trounson A.O., Stagespecific appearance of the mouse antigen TEC3 in normal and nuclear transfer bovine embryos: Re-expression after nuclear transfer, Mol. Reprod. Dev. 37 (1994) 27-33.

[40] Wakayama T., Perry A.C.F., Yuccotti M., Johnson K.R., Yanagimachi R., Full-term development of mice from enucleated oocytes injected with cumulus cell nuclei, Nature 394 (1998) 369-374.

[41] Walker S.K., Hartwich K.M., Seamark R.F., The production of unusually large offspring following embryo manipulation: Concepts and challenges, Theriogenology 45 (1) (1996) $111-120$.

[42] Wells D.N., Misica P.M., Tervit H.R., Production of cloned calves following nuclear transfer with cultured adult mural granulosa cells, Biol. Reprod. 60 (4) (1999) 996-1005.

[43] Westhusin M.E., Arcellana-Panlilo M., Harvey M., Jones K., Schultz G.A., Gene expression in cloned bovine embryos, in: Application of Molecular Biology to Reproduction, IETS Satellite Symposium, Calgary, 1995.

[44] Willadsen S.M., Nuclear transplantation in sheep embryos, Nature 320 (1986) 63-65.

[45] Wilmut I., Schnieke A.E., Mcwhir J., Kind A.J., Campbell K.H.S,, Viable offspring derived from fetal and adult mammalian cells, Nature 385 (6619) (1997) 810-813.

[46] Zimmermann J.W., Schultz R.M., Analysis of gene expression in the preimplantation mouse embryo: Use of mRNA differential display, Proc. Natl. Acad. Sci. USA/Dev. Biol. 91 (1994) $1-5$. 